\title{
PENERAPAN DANA BERGULIR KELOMPOK SIMPAN PINJAM PEREMPUAN PADA PNPM-MPD DI KECAMATAN WANGON, KABUPATEN BANYUMAS
}

\author{
Taufik Margi widodo'), Wita Ramadhanti2), Hijroh Rokhayati2) \\ 1) PT. Nusantara Sakti (NSS) \\ Jl. Wonosari-Yogyakarta KM.1 Jawa Tengah Indonesia \\ 2)Dosen Akuntansi Fakultas Ekonomi dan Bisnis Universitas Jenderal Soedirman \\ Jl. HR. Boenyamin No. 708 Purwokerto 53122 Jawa Tengah Indonesia \\ *corresponding author: fik.margiwidodo@gmail.com
}

\begin{abstract}
Abstrak
Implementasi pemberdayaan masyarakat perdesaan terutama dalam bentuk dana bergulir yang kurang diperhatikan adalah pengelolaan keuangan, dan kemampuan pengelolaan atau skill yang mampu mendukung kelompok usaha perempuan. Melalui salah satu program Simpan Pinjam Perempuan (SPP), diharapkan dapat meningkatkan kesejahteraan masyarakat, terutama kaum perempuan dan juga dapat menurunkan angka kemiskinan dikalangan masyarakat, mulai dari tahap perencanaan, pelaksanaan, pengendalian dan evaluasi. Tujuan dari penelitian ini adalah untuk mengetahui signifikansi perbedaan pendapatan (kinerja keuangan) dan kesejahteraan kelompok sebelum dan sesudah program SPP pada Program Nasional Pemberdayaan Masyarakat Pedesaan (Perdesaan) PNPM-MPd. Penelitian ini menggunakan teknik pembanding berdasarkan mix method dengan objek penelitian yaitu kelompok SPP di Kecamatan Wangon, Kabupaten Banyumas. Hipotesis diuji dengan menggunakan uji non parametrik melalui uji wilcoxon dan wawancara mendalam. Hasil penelitian menunjukkan bahwa ada peningkatan tingkat pendapatan dan kesejahteraan, yang berarti terdapat perbedaan tingkat pendapatan dan kesejahteraan sebelum dan sesudah mengikuti program SPP.
\end{abstract}

Kata Kunci: Program Nasional Pemberdayaan Masyarakat Mandiri Perdesaan (PNPM-MPd), Simpan Pinjam Perempuan (SPP), Pendapatan, Kinerja Keuangan.

\begin{abstract}
The implementation of society empowerment, especially in the form of revolving funds (saving and loan) that consider less is financial management, and guidance on life skills that are able to support women business group. Through one of its program Women Saving and Loan / Simpan Pinjam Perempuan (SPP), it is expected to improve the welfare of people, especially womenand also applied poverty alleviation mechanism involving elements of society, start from planning, implementation, control and evaluation stages. The purpose of this studys are to determine the significance of differences revenue (financial performance) and the welfare of the group before and after the SPP program of National Program for (Rural) Society Empowerment / Program Nasional Pemberdayaan masyarakat Mandiri Perdesaan PNPM-MPd. These study used comparative technique bases on mix method with research object are SPP groups in Wangon Sub-District, Banyumas District. Hypothesis is tested by using non-parametric test through wilcoxon test and in-depth interviews. The results showed that there is an increase in revenue and welfare level, which means there are differences in revenue and welfare level before and after join the SPP program.
\end{abstract}

Keywords: National Program for (Rural) Society Empowerment (PNPM-MPd), Women Saving and Loan (SPP), Revenue, Financial Performance.

\section{PENDAHULUAN}

Badan Pusat Statistik (BPS) melansir jumlah pengangguran pada Agustus 2014 sebanyak 7,24 juta jiwa, atau berkurang sebanyak 170.000 jiwa dibanding jumlah pengangguran pada Agustus 2013. Namun, jika dibandingkan dengan data Februari 2014, jumlah pengangguran naik sebanyak 90.000 jiwa. Pada Februari 2014 jumlah pengangguran tercatat sebanyak 7,15 juta jiwa. 
Penerapan Dana Bergulir Kelompok Simpan Pinjam Perempuan...

Melalui Program Nasional Pemberdayaan masyarakat Mandiri (PNPM Mandiri), diterapkan mekanisme upaya penanggulangan kemiskinan yang melibatkan unsur masyarakat, mulai dari tahap perencanaan, pelaksanaan, hingga tahap pengendalian serta evaluasi. Melalui proses pembangunan partisipatif dan kemandirian masyarakat. Hal tersebut dapat meningkatkan peran masyarakat sebagai subjek bukan lagi sebagai objek dalam mengatasi kemiskinan.

Pada tahun 2009 sampai sekarang seluruh kecamatan di Indonesia telah tercakup dalam PNPM Mandiri dan sampai tahun 2014 direncanakan PNPM Mandiri tetap akan menjangkau seluruh kecamatan di Indonesia. PNPM Mandiri sebagai instrumen penanggulangan kemiskinan merupakan kewajiban bersama pemerintahan daerah dan pusat guna memperkuat pelaksanaan urusan bersama antara pusat dan daerah tersebut. Menteri Keuangan selaku Pengelola Fiskal dan Bendahara Umum Negara perlu mengatur penyediaan dan tata cara pengelolaan dana urusan bersama pusat dan daerah, khususnya untuk Program Nasional Pemberdayaan Masyarakat Mandiri Perdesaan (PNPM-MPd) dan Program Nasional Pemberdayaan Masyarakat Mandiri Perkotaan (PNPM-MP).

Penyaluran dana di Kabupaten Banyumas melalui PNPM Mandiri dan program bantuan lain, berhasil menurunkan angka kemiskinan dari 33,6 \% pada tahun 2008 dengan jumlah penduduk 1,5 juta orang, menjadi 27,4 \% pada tahun 2010 dengan jumlah penduduk 1,8 juta orang, dimana jumlah rumah tangga miskin di Kabupaten Banyumas pada tahun 2010 sebesar 141.233 rumah tangga. Dana bantuan PNPM Mandiri yang telah digulirkan sejak tahun 2008 hingga 2010 mencapai Rp147,5 miliar, sedangkan pada tahun 2010 telah digulirkan dana sebesar Rp45 miliar bersumber dari Anggaran Pendapatan Dan Belanja Negara (APBN) dan Rp6 miliar bersumber dari Anggaran Pendapatan Dan Belanja Daerah (APBD). Dana tersebut digulirkan untuk 19 kecamatan yang terdistribusi dalam 234 desa, dimana dana PNPM tersebut diperuntukkan bagi pelayanan dasar (Sumber: Sigap Bencana \& Bansos, 14 Januari 2011).

Salah satu cara pemerintah untuk meningkatkan kesejahteraan masyarakat adalah dengan memberikan bantuan dana bergulir melalui program PNPM-MPd yang akan digunakan masyarakat untuk mengembangkan usaha mereka. Dana Bergulir merupakan dana abadi milik masyarakat yang dikelola oleh masyarakat. Salah satu programnya melalui kegiatan perguliran kelompok Simpan Pinjam Perempuan (SPP).

Saat ini kegiatan perguliran SPP telah berjalan dan melayani masyarakat lebih dari 5 tahun. Secara umum asset kegiatan dana bergulir rata-rata setiap kecamatan mencapai lebih dari Rp2 milyar. Kegiatan dimaksud telah melayani rata-rata 150 kelompok SPP di setiap kecamatan di seluruh Indonesia. Dana bergulir ini diharapkan dapat membantu peningkatan usaha sehingga dapat menghasilkan manfaat kepada pemiliknya. Dana bergulir yang diberikan kepada kelompok perempuan kepada PNPM-MPd sebagai bentuk pemberdayaan ekonomi rumah tangga didesa. Dana bergulir yang diberikan kepada kelompok masyarakat (terutama kaum perempuan) diharapkan dapat 
digulirkan kembali kepada kelompok yang lainnya, sehingga perputaran uang semakin cepat dan banyak kaum perempuan yang tersentuh dengan program tersebut.

Pelaksanaan pemberdayaan masyarakat khususnya dalam bentuk dana bergulir (simpan pinjam) yang dirasa kurang adalah manajemen pengelolaan keuangan, serta pembinaan pada kecakapan hidup atau keterampilan (skill) yang bersifat bisa mendukung usaha kelompok kaum perempuan. Beberapa kegiatan PNPM-MPd, khususnya kegiatan Kelompok SPP pun terjadi masalah salah satunya sebagian masyarakat tidak menggunakan dana pinjaman untuk modal usaha, bahkan digunakan untuk keperluan sehari-hari. Masih terdapat permasalahan mengenai penggunaan dana bergulir maupun kinerja kelompok SPP. Hal ini dapat mengidentifikasikan bahwa penerapan PNPM-MPd masih belum efektif. di Kabupaten Banyumas, pelaksanaan PNPM-MPd juga sudah dilakukan. Tetapi sampai saat ini kemiskinan masih menjadi permasalahan yang belum bisa terselesaikan.

Masalah yang teridentifikasi pada kegiatan simpan pinjam khusus perempuan adalah pemberdayaan ekonomi rumah tangga miskin yang belum dijalankan, tabungan anggota tidak berkembang, proses pencairan kredit relatif lama, belum maksimalnya fasilitasi kelompok dalam pengembangan usaha anggota dan pembuatan aturan-aturan kelompok (Hamdi et al 2013). Sedangkan Surya (2011), yang mengambil objek penelitian di Kota Padang mengungkapkan bahwa dana bergulir ini tidak hanya efektif untuk meningkatkan kinerja usaha mikro dan kecil, tapi yang lebih penting lagi adalah dampak dari adanya perubahan pada ketersediaan kas, efektifitas penggunaan aktiva dan peningkatan laba bersih. Hasil penelitian ini sesuai dengan penelitian yang dilakukan oleh Rantung (2014), dan Zhou (2009) yang mengungkapkan bahwa pelaksanaan program dana bergulir memberikan dampak positif untuk masyarakat. Berdasarkan gap research diatas terdapat hasil yang berbeda, sehingga penelitian ini mengkaji tentang apakah penyaluran dana bergulir melalui program SPP dapat meningkatkan kesejahteraan masyarakat khususnya kaum perempuan yang diukur melalui kinerja keuangan (pendapatan) di Kecamatan Wangon.

Di Kecamatan Wangon, UPK Wangon telah berhasil mengelola kegiatan SPP sejak tahun 2001 dan di Kabupaten Banyumas, hanya di Kecamatan Wangon yang melaksanakan program SPP dan Usaha Ekonomi Produktif (UEP). Sehingga analisis yang dilakukan dapat menghasilkan informasi mengenai kinerja keuangan dari proses pengelolaan kegiatan serta untuk melihat manfaat atau hasil dari keberhasilan pengelolaan kegiatan tersebut.

Pengunaan kinerja keuangan pada penerapan dana bergulir melalui kegiatan SPP dilakukan dengan perbandingan pendapatan sebelum dan sesudah menerima bantuan dana bergulir. Perbandingan pendapatan dan tingkat kesejahteraan akan diuji secara statistik dengan menggunakan teknik In-depth Interview dan uji sampel data berpasangan.

Berdasarkan latar belakang tersebut, rumusan masalah yang akan diteliti adalah: 1) Apakah terdapat perbedaan tingkat pendapatan yang signifikan pada kelompok simpan pinjam perempuan di 
Penerapan Dana Bergulir Kelompok Simpan Pinjam Perempuan...

Kecamatan Wangon sebelum dan sesudah mengikuti program SPP PNPM-MPd. 2) Apakah program SPP PNPM-MPd memberi pengaruh dalam peningkatan kesejahteraan pada kaum perempuan.

Penelitian ini bertujuan untuk mengetahui signifikansi perbedaan pendapatan usaha kelompok SPP antara sebelum dan sesudah mengikuti program SPP PNPM-MPd serta untuk menilai apakah program SPP PNPM-MPd memberikan pengaruh positif dalam peningkatan kesejahteraan kaum perempuan.

Penelitian ini memberikan kontribusi antara lain: 1) Kontribusi teoritis, dengan memberikan tambahan hasil empiris mengenai pemanfaatan dana bergulir pada kelompok simpan pinjam perempuan pada PNPM-MPd baik secara teori maupun empiris; 2)Kontribusi praktis, antara lain: a) Pemerintah, hasil penelitian ini sebagai bahan pertimbangan untuk mengetahui pentingnya penyaluran dana bergulir program SPP PNPMMPd pada kelompok perempuan untuk meningkatkan kesejahteraan, b) masyarakat, penelitian ini dapat dijadikan pembelajaran bagi masyarakat tentang pentingnya peran PNPM-MPd dalam mengatasi kemiskinan salah satunya melalui program SPP.

\section{TINJAUAN PUSTAKA}

\section{Teori Agensi}

Keputusan pendanaan berkaitan dengan pemilihan sumber dana baik yang berasal dari dalam maupun dari luar perusahaan sangat mempengaruhi nilai perusahaan. Sumber dana perusahaan dari internal berasal dari laba ditahan dan depresiasi. Sumber dana eksternal perusahaan berasal dari kreditur yang merupakan utang bagi perusahaan. Dana yang diperoleh dari pemilik perusahaan merupakan modal sendiri.

Jensen dan Meckling (1976), menjelaskan hubungan keagenan didalam teori agensi (agency theory) bahwa perusahaan merupakan kumpulan kontrak (nexus of contract) antara pemilik sumber daya ekonomis (principal) dan manajer (agent) yang mengurus penggunaan dan pengendalian sumber daya tersebut.

Menurut agency theory, principal selaku pemegang saham atau owner mempekerjakan agent atau manajer untuk mengelola resource yang dimiliki secara efisien dan efektif untuk memberikan profit dan sustainability perusahaan. Permasalahan yang sering terjadi yaitu adanya conflict of interest antar principal dan agent yang dapat menimbulkan masalah agency atau agency problem, dimana agent tidak bertindak sesuai dengan kepentingan principal dan hal ini akan berpengaruh kepada kinerja perusahaan. Pemisahan kepemilikan dan manajemen yang melebar dapat menyebabkan adanya kepentingan tertentu dari manajemen untuk membuat keputusan yang tidak sesuai dengan kepentingan shareholder (Jensen dan Meckling, 1976).

Oleh karena itu, manajemen wajib mempertanggungjawabkan semua upayanya kepada pemegang saham. Karena unit analisis dalam teori keagenan adalah kontrak yang melandasi hubungan antara prinsipal dan agen, maka fokus dari teori ini adalah pada penentuan kontrak yang 
paling efisien yang mendasari hubungan antara prinsipal dan agen. Untuk memotivasi agen maka prinsipal merancang suatu kontrak agar dapat mengakomodasi kepentingan pihak-pihak yang terlibat dalam kontrak keagenan.

Teori keagenan juga menjelaskan konflik antara kepentingan manajemen dan kepentingan pemegang saham sering kali bertentangan. Konflik dalam agency cost berarti konflik antara pemegang saham dengan kreditur dan konflik antara pemegang saham dengan pihak manajemen. Hal tersebut terjadi karena manajer cenderung berusaha mengutamakan kepentingan pribadi. Kreditur lebih memperhatikan kemampuan perusahaan untuk membayar kembali utangnya, sedangkan pemegang saham lebih memperhatikan kemampuan perusahaan dalam meraih laba yang banyak.

\section{Kesejahteraan Melalui Pembangunan Ekonomi}

Menurut Segel dan Bruzy (1998), Kesejahteraan sosial adalah kondisi sejahtera dari suatu masyarakat. Kesejahteraan sosial meliputi kesehatan, keadaan ekonomi, kebahagiaan, dan kualitas hidup rakyat.

Tingkat kesejahteraan masyarakat dapat diukur melalui pendidikan, kesehatan, penghasilan, dan pelayanan social. Tetapi faktor-faktor tersebut tidak akan terpenuhi tanpa adanya pemerataan pendapatan. Pemerataan pendapatan mencerminkan meratanya hasil pembangunan suatu daerah atau Negara sehingga dapat meningkatkan pembangunan ekonomi suatu negara.

Pembangunan ekonomi adalah usaha-usaha untuk meningkatkan taraf hidup riil per kapita. Jadi tujuan pembangunan ekonomi disamping untuk menaikkan pendapatan nasional riil juga untuk meningkatkan produktivitas (Irawan dan Suparmoko, 2002).

\section{Pengukuran Kinerja Dana Bergulir bagi Kelompok Simpan Pinjam Perempuan pada PNPM-} MD

a) Pengertian Kinerja Keuangan

Kinerja keuangan mengindikasikan apakah strategi perusahaan, implementasi strategi, dan segala inisiatif perusahaan memperbaiki laba perusahaan. Pengukuran kinerja mencerminkan pengukuran hasil atas keputusan strategis, operasi dan pembiayaan dalam suatu perusahaan. Kinerja keuangan suatu perusahaan sangat bermanfaat bagi berbagai pihak (stakeholders) seperti investor, kreditur, analis, konsultan keuangan, pialang, pemerintah, dan pihak manajemen sendiri (Harjito 2008).

Kinerja keuangan suatu perusahaan dapat diartikan sebagai prospek atau masa depan, pertumbuhan dan potensi perkembangan yang baik bagi perusahaan. Informasi kinerja keuangan diperlukan untuk menilai perubahan potensial sumber daya ekonomi, yang mungkin dikendalikan di masa depan dan untuk memprediksi kapasitas produksi dari sumber daya yang ada (Barlian, 2003). 
Penerapan Dana Bergulir Kelompok Simpan Pinjam Perempuan...

Secara umum dapat dikatakan bahwa kinerja keuangan adalah prestasi yang dapat dicapai oleh perusahaan dibidang keuangan dalam suatu periode tertentu yang mencerminkan tingkat kesehatan perusahaan. Disisi lain kinerja keuangan menggambarkan kekuatan struktur keuangan suatu perusahaan dan sejauh mana asset yang tersedia, perusahaan sanggup meraih keuntungan. Hal ini berkaitan erat dengan kemampuan manajemen dalam mengelola sumber daya yang dimilki perusahaan secara efektif dan efisien.

Program pemerintah tidak mengukur profit atau lost seperti organisasi for-profit, tapi lebih mengedepankan outcome atau dampak dari kegiatan tersebut. Pengelolaan sebuah organisasi harus menentukan indikator tertentu untuk mengukur tingkat keberhasilan atau kinerja dan apakah tujuan telah tercapai. Selain melalui indicator kinerja, analisis kinerja juga diperoleh dari penilaian atas ukuran kinerja yang dicapai. Penilaian kinerja dana bergulir ini akan terlihat dari perbandingan kinerja keuangan (pendapatan) sebelum dan sesudah mendapat bantuan dana bergulir dari program PNPM Mandiri.

b) Dana Bergulir

Menurut PERATURAN MENTERI KEUANGAN NOMOR 218/ PMK. 05 / 2009 pasal 1 Dana Bergulir adalah dana yang dialokasikan oleh Kementerian Negara/Lembaga/Satuan Kerja Badan Layanan Umum untuk kegiatan perkuatan modal usaha bagi koperasi, usaha mikro, kecil, menengah, dan usaha lainnya yang berada di bawah pembinaan Kementerian Negara atau Lembaga. Pada pasal 2, Dana Bergulir bertujuan untuk membantu perkuatan modal usaha guna pemberdayaan koperasi, usaha mikro, kecil, menengah, dan usaha lainnya dalam upaya penanggulangan kemiskinan, pengangguran, dan pengembangan ekonomi nasional.

c) Pentingnya Kelompok Simpan Pinjam Perempuan pada PNPM-MPd

Kegiatan ekonomi dari kaum perempuan (SPP) diharapkan menjadi penunjang peningkatan perekonomian rumah tangga miskin yang digerakkan kaum perempuan. Selain karena prosedur peminjaman yang mudah bagi warga desa, proses pendanaan usaha ini juga dikelola sendiri oleh masyarakat setempat. Setiap kaum perempuan (secara berkelompok) dari desa-desa di lokasi program memiliki kesempatan untuk memperoleh modal.

\section{PERUMUSAN HIPOTESIS}

Pengukuran kinerja dapat dinilai dari seberapa besar pendapatan yang dihasilkan. Evaluasi terhadap pendapatan PNPM-MPd pada kelompok SPP diukur perdasarkan perbedaan pendapatan kelompok SPP sebelum dan sesudah menerima bantuan dana bergulir dari program SPP PNPM-MPd. Pembuatan model penelitian ini akan membantu dalam mengumpulkan data-data valid. Berikut beberapa penelitian terdahulu yang relevan untuk mengungkapkan fakta mengenai kinerja dana bergulir PNPM Mandiri pada kelompok SPP di Kecamatan Wangon, Banyumas. 
Surya (2011), melakukan penelitian mengenai analisis kinerja dana bergulir PNPM Mandiri di Kecamatan Lubuk begalung Kota Padang. Hasil penelitian menunjukan bahwa rasio likuiditas pada Usaha Kecil Menengah (UKM) anggota Kelompok Swadaya Masyarakat (KSM) yang mendapat bantuan dana bergulir sebagian besar tidak memperlihatkan perubahan yang signifikan. Sedangkan untuk rasio profitabilitas pada UKM anggota KSM yang mendapat bantuan dana bergulir sebagian besar memperlihatkan perubahan yang signifikan. Selain itu, dampak yang dapat dilihat dengan adanya bantuan dana bergulir adalah adanya peningkatan kualitas hidup berdasarkan indikator pendapatan, perumahan, kesehatan, pendidikan dan gizi.

Hamdi et al (2013), melakukan penelitian mengenai kegiatan simpan pinjam khusus perempuan di Kecamatan Semparuk, Sambas. Hasil dari penelitian ini menunjukan masalah-masalah yang teridentifikasi antara lain: pemberdayaan ekonomi Rumah Tangga Miskin (RTM) belum dilaksanakan, tabungan anggota tidak berkembang, proses pencairan kredit yang relatif lama, belum maksimalnya peran pelaku program dalam fasilitasi kelompok terutama dalam pengembangan usaha anggota. Beberapa alternatif strategi yang dapat dilaksanakan UPK secara urutan prioritas adalah: meningkatkan pelayanan, melakukan perluasan pasar dan jaringan pemasaran kredit, memaksimalkan peran pelaku program, mempertahankan komitmen terhadap pengembangan SPP, meningkatkan promosi program, meningkatkan pembinaan kelompok, dan pengembangan produk simpanan dan pinjaman.

Rantung (2014), melakukan penelitian mengenai efektivitas kegiatan kelompok simpan pinjam khusus perempuan di Kecamatan Kauditan kabupaten Minahasa Utara. Hasil dari Penelitian ini menunjukan bahwa tingkat efektifitas di Kecamatan Kauditan periode 2012-2013 adalah sebesar 93\%. Hal ini menunjukkan bahwa tingkat efektifitas mencapai tingkat yang disebut efektif.

Zhou (2009) melakukan penelitian mengenai faktor determinasi donasi organisasi non-profit di Cina. Penelitian ini menggunakan random-effect model untuk menguji faktor-faktor penentu yang mempengaruhi sumbangan swasta untuk organisasi dengan menggunakan data panel tingkat 31provinsi dari tahun 1997-2008. Hasilnya Pemerintah harus terus meningkatkan subsidi atau hibah, mendorong organisasi untuk berperilaku self-produktif, membangun pasar aktif dan dinamis untuk pengembangan negara China yang melakukan organisasi non-profit.

Berdasarkan hasil penelitian sebelumnya, menunjukan bahwa adanya bantuan dana bergulir memberikan peningkatan kualitas pendapatan penerima. Oleh karena itu, penelitin ini menduga bahwa terdapat perbedaan pendapatan pada kelompok simpan pinjam perempuan sebelum dan sesudah mengikuti program SPP PNPM Mandiri Perdesaan. Selanjutnya penelitian ini juga menduga bahwa terdapat perbedaan tingkat kesejahteraan kaum perempuan sebelum dan sesudah mengikuti program SPP PNPM Mandiri Perdesaan. Hipotesis penelitian yang kami ajukanadalah sebagai berikut:

$H_{1}$ : Terdapat perbedaan pendapatan pada kelompok simpan pinjam perempuan sebelum dan sesudah mengikuti program SPP PNPM Mandiri Perdesaan. 
Penerapan Dana Bergulir Kelompok Simpan Pinjam Perempuan...

$\mathrm{H}_{2}$ : $\quad$ Terdapat perbedaan tingkat kesejahteraan kaum perempuan sebelum dan sesudah mengikuti program SPP PNPM Mandiri Perdesaan.

Adapun rerangka pemikiran dalam penelitian ini disajikan dalam gambar 1.

\begin{tabular}{|c|c|}
$\begin{array}{c}\text { Pendapatan dan kesejahteraan } \\
\text { Kelompok Simpan Pinjam } \\
\text { Perempuan Kecamatan Wangon } \\
\text { (sebelum mengikuti program } S P P)\end{array}$ & $\quad \begin{array}{c}\text { Pendapatan dan kesejahteraan } \\
\text { Kelompok Simpan Pinjam } \\
\text { Perempuan Kecamatan Wangon } \\
\text { (setelah mengikuti program } S P P \text { ) }\end{array}$ \\
\hline
\end{tabular}

Gambar 1: Rerangka Pemikiran

Kerangka pemikiran diatas menjelaskan bahwa penelitian ini terdiri dari perbandingan variabel pendapatan dan tingkat kesejahteraan antara sebelum dan sesudah mengikuti program SPP.

\section{METODE PENELITIAN}

Jenis penelitian ini adalah penelitian komparatif berbasis Mix Method karena menjelaskan tentang perbedaan pendapatan masyarakat sebelum dan sesudah menerima bantuan dana bergulir. Creswell (dalam Sugiyono, 2012) menyatakan bahwa metode penelitian kombinasi merupakan sebuah pendekatan dalam penelitian yang mengkombinasikan atau menghubungkan antara metode penelitian kuantitatif dan kualitatif. "Sequential Exploratory Strategy in mie research involves a first phase of qualitative data collection and analysis followed by a second phase of quantitative data collection and analysis that build on the result of the first qualitative phase" (Creswell dalam sugiyono, 2009). Bobot metode lebih pada metode tahap pertama yaitu metode kualitatif dan selanjutnya dilengkapi dengan metode kuantitatis. Kombinasi data kedua metode bersifat connecting (menyambung) hasil penelitian tahap pertama (hasil penelitian kualitatif) dan tahap berikutnya (hasil penelitian kuantitatif).

Penelitian ini mengambil tempat atau objek penelitian di Kecamatan Wangon. Alasan pemilihan tempat tersebut karena keberhasilan UPK dalam menjalankan program SPP di Kecamatan Wangon dan karena Kecamatan Wangon telah merhasil menjalankan program SPP dan UEP PNPMMPd sampai saat ini. Objek penelitian yang diteliti adalah pendapatan (kinerja keuangan) kelompok simpan pinjam perempuan di Kecamatan Wangon yang dilihat dari perbedaan pendapatan antara sebelum dan sesudah mengikuti program SPP PNPM-MPd.

Sugiyono (2012), menjelaskan populasi adalah wilayah generalisasi yang terdiri atas: objek atau subjek yang mempunyai kualitas dan karakteristik tertentu yang ditetapkan oleh peneliti untuk dipelajari dan kemudian ditarik kesimpulannya. Populasi penelitian ini adalah kelompok SPP di Kecamatan Wangon berjumlah 47 kelompok yang diambil dari setiap perwakilan kelompok untuk dijadikan sampel penelitian. Sumber data yang diperlukan dalam penelitian ini berupa data primer yang diperoleh berupa kata-kata dan data sekunder berupa dokumen-dokumen. 


\section{Teknik pengumpulan data}

a. Kuesioner

Kuesioner adalah pertanyaan terstruktur yang diisi sendiri oleh responden atau diisi oleh pewawancara yang membacakan pertanyaan dan kemudian mencatat jawaban yang diberikan. Pertanyaan yang akan diberikan pada kuesioner ini adalah pertanyaan menyangkut fakta dan pendapat responden. Kuisioner dibagikan kepada responden yaitu perwakilan dari kelompok SPP di Kecamatan Wangon. Kuisioner terdiri dari dua bagian yaitu identitas responden dan pertanyaan utama dari tingkat kesejahteraan sebelum dan sesudah mengikuti program SPP. Pertanyaan dalam kuisioner yang akan dijawab oleh responden diberi bobot dengan menggunakan skala Likert.

Skala Likert berguna untuk menunjukkan tanggapan responden terhadap pernyataan yang diberikan. Skala likert merupakan skala pengukuran ordinal. Hasil pengukurannya hanya dapat dibuat peringkat tanpa diketahui besar selisih antara satu tanggapan dengan tanggapan lain. Dalam penelitian ini, 1 = sangat tidak baik, $2=$ tidak baik, $3=$ biasa saja, $4=$ baik, dan $5=$ sangat baik .

Hasil dari rataan dan simpangan baku tersebut dipetakan ke rentang skala dengan mempertimbangkan informasi interval sebagai berikut:

$$
\text { interval }=\frac{\text { nilai tertinggi }- \text { nilai terendah }}{\text { banyak kelas }}=\frac{5-1}{5}=0.8
$$

Setelah besarnya skala diketahui, kemudian dibuat rentang skala agar dapatdiketahui dimana letak rataan penilaian respon terhadap setiap unsure diferensiasinya dan sejauh mana ragamnya. Rentang skala tersebut adalah:

Tabel 1. Rentang dari Hasil Rataan Berdasarkan Skala Likert

\begin{tabular}{|l|c|c|}
\hline Nilai & $\begin{array}{c}\text { Kesejahteraan Sebelum } \\
\text { Mengikuti SPP }\end{array}$ & $\begin{array}{c}\text { Kesejahteraan Sesudah } \\
\text { Mengikuti SPP }\end{array}$ \\
\hline $1.0-1.8$ & Sangat Tidak Baik & Sangat Tidak Baik \\
\hline $1.8-2.6$ & Tidak Baik & Tidak Baik \\
\hline $2.6-3.4$ & Biasa Saja & Biasa Saja \\
\hline $3.4-4.2$ & Baik & Baik \\
\hline $4.2-5.0$ & Sangat Baik & Sangat Baik \\
\hline
\end{tabular}

b. Wawancara

Wawancara terstruktur adalah wawancara dengan menggunakan daftar pertanyaan yang telah disiapkan sebelumnya. Pertanyaan yang sama diajukan kepada semua responden, dalam kalimat dan urutan yang seragam.

c. Dokumentasi

Pengumpulan data-data dengan cara mengambil dari catatan, dokumentasi, administrasi yang sesuai dengan penelitian. 


\section{Definisi Operasional Variabel}

Variabel pada penelitian ini adalah 1) Pendapatan dan kesejahteraan kelompok SPP sebelum menerima bantuan dana bergulir dari PNPM Mandiri Perdesaan. 2) Pendapatan dan kesejahteraan kelompok SPP setelah menerima bantuan dana bergulir dari PNPM Mandiri Perdesaan.

Pendapatan adalah arus masuk bruto dari manfaat ekonomi yang timbul dari aktivitas normal entitas selama suatu periode jika arus masuk tersebut mengakibatkan kenaikan ekuitas, yang tidak berasal dari kontribusi penanam modal (PSAK nomor 23 paragraf 6).

SPP adalah kegiatan yang dilakukan oleh kaum perempuan dengan aktifitas/kegiatan pengelolaan dana simpanan dan pengelolaan dana pinjaman. Hal ini bertujuan untuk mengembangkan potensi kegiatan simpan pinjam pedesaan, kemudahan akses pendanaan usaha skala mikro, pemenuhan kebutuhan pendanaan sosial dasar, dan memperkuat kelembagaan kegiatan kaum perempuan.

\section{Teknik Analisis Data}

\section{a. Uji Instrumen Penelitian}

1) Uji Instrumen Kualitatif

Pengujian instrument data kualitatif dilakukan menggunakan uji kredibilitas data yang dapat dilakukan adalah dengan metode triangulasi data penelitian. Menurut Moleong (2011), triangulasi dapat ditempuh dengan cara sebagai berikut:

a) Membandingkan data pengamatan dengan data hasil wawancara

b) Membandingkan apa yang dikatakan responden didepan umum dengan apa yang dikatakan secara pribadi

c) Membandingkan apa yang dikatakan sewaktu diteliti dengan sepanjang waktu

d) Membandingkan keadaan dan perspektif seseorang dengan berbagai pendapat dan pendangan orang

e) Membandingkan hasil wawancara dengan isi dokumen yang berkaitan

Pada penelitian ini juga menggunakan teknik wawacara mendalam untuk memperoleh informasinya. Wawancara merupakan alat rechecking atau pembuktian terhadap informasi atau keterangan yang diperoleh sebelumnya.

Wawancara mendalam (in-depth interview) adalah proses memperoleh keterangan untuk tujuan penelitian dengan cara tanya jawab sambil bertatap muka antara pewawancara dengan informan atau orang yang diwawancarai, dengan atau tanpa menggunakan pedoman (guide) wawancara, di mana pewawancara dan informan terlibat dalam kehidupan sosial yang relatif lama (Sutopo, 2006). 
2) Uji Instrumen Kuantitatif

a. Uji Normalitas

Menurut Imam Ghozali (2007), tujuan dari uji normalitas adalah sebagai berikut:

"Uji normalitas bertujuan untuk mengetahui apakah masing-masing variabel berdistribusi normal atau tidak.Uji normalitas diperlukan karena untuk melakukan pengujian-pengujian variabel lainnya dengan mengasumsikan bahwa nilai residual mengikuti distribusi normal.jika asumsi ini dilanggar maka uji statistik menjadi tidak valid dan statistik parametrik tidak dapat digunakan."

Uji normalitas dalam penelitian ini menggunakan analisa Shapiro-Wilks. Menurut Santoso (2008), menjelaskan analisa Shapiro-Wilks sebagai berikut:

i. Ada pedoman pengambilan keputusan :Angka signifikansi (Sig) $>\alpha=0,05$ maka data berdistribusi normal

ii. Angka signifikansi (Sig) $<\alpha=0,05$ maka data tidak berdistribusi normal.

Pengujian normalitas dalam penelitian ini dilakukan dengan menggunakan bantuan SPSS 16.0 for windows.

\section{Uji Hipotesis}

\section{a. Analisis data Kualitatif}

Analisis data dilakukan menggunakan analisis interaktif. Menurut Miles dan Huberman (2007) analisa ini dilakukan dengan melalui prosedur sebagai berikut:

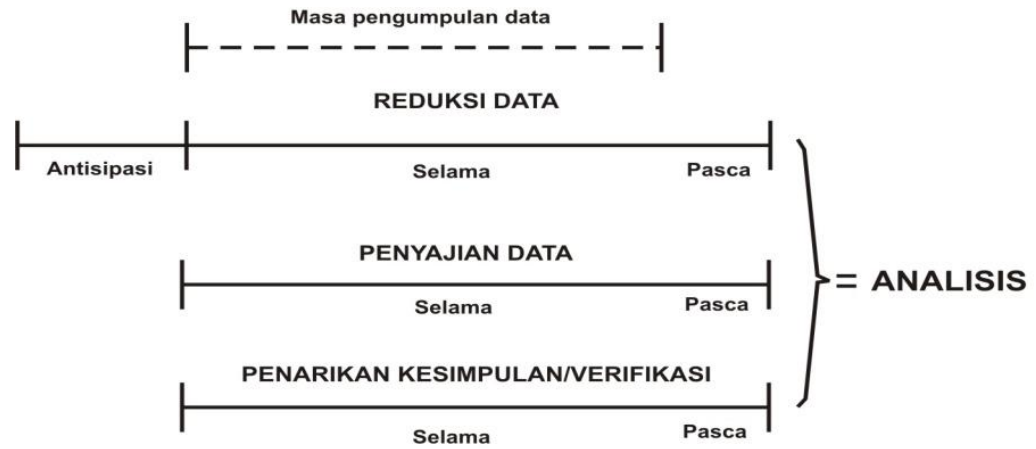

Gambar 2. Komponen-komponen Analisis Data

1) Data reduksi

Reduksi data diartikan sebagai proses pemilihan, pemusatan perhatian pada penyederhanaan, pengabstrakan, dan transformasi data "kasar" yang muncul dari càtatan-catatan tertulis di lapangan. Sebagaimana kita ketahui, reduksa data, berlangsung terus-menerus selama proyek yang berorientasi kualitatif berlangsung. Sebenarnya bahkan sebelum data benar-benar terkimpul, antisipasi ákan adanya reduksi data sudah tampak waktu penelitinya memutuskan (acapkali tanpa disadari sepenuhnya). 
2) Penyajian data

Alur penting yang kedua dan kegiatan analisis adalah penyajian data. Miles dan Huberman membatasi suatu "penyajian" sebagai sekumpulan informasi tersusun yang memberi kemungkinan adanya penarikan kesimpulan dan pengambilan tindakan.

3) Penarikan kesimpulan

Kegiatan analisis ketiga yang penting adalah menarik kesimpulan dan verifikasi. Dari permulaan pengumpulan data, seorang penganalisis kualitatif mulai mencari arti benda-benda, mencatat keteraturan. penjelasan, konfigurasi-konfigurasi yang mungkin, alur sebab- akibat, dan proposisi. Menurut pandangan Miles dan Huberman, hanyalah sebagian dan satu kegiatan dan konfigurasi yang utuh. Kesimpulan-kesimpulan juga diverifikasi selama penelitian berlangsung.

\section{b. Analisis Data Kuantitatif}

Pada bagian penyajian statistik dapat dilakukan dengan menguji tingkat kesejahteraan masyarakat melalui perbandingan pendapatan sebelum dan sesudah adanya program Dana Bergulir PNPM-MPd. Dari hasil pengujian tersebut diharapkan mampu untuk mengetahui apakah ada perbedaan atau tidak pada tingkat kesejahteraan masyarakat setelah menerima program Dana Bergulir PNPM-MPd. Selanjutnya, pada tahap pengujian perbedaan pendapatan dan kesejahteraan sebelum mengikuti program SPP dan pendapatan dan kesejahteraan sesudah mengikuti program SPP dapat dilakukan dengan metode Uji Data Dua Sampel Berhubungan (Dependent) dengan uji wilxocon dua sisi dan mencari selisih rata-rata antar aspek berbasis skala likert.

1) Uji Wilxocon (dua sisi)

2) Formulasi rumus Wilxocon test

$$
Z=\frac{\mathrm{T}-\frac{\mathrm{N}(\mathrm{N}+1)}{4}}{\frac{\mathrm{N}(\mathrm{N}+1)(2 \mathrm{~N}+1)}{24}}
$$

Keterangan :

$\mathrm{N}$ = jumlah pasangan yang dijenjangkan

$\mathrm{T}=$ jumlah jenjang minoritas yang tandanya sama

Adapun langkah - langkah dalam pengujian hipotesis adalah sebagai berikut:

i. Hipotesis

Bentuk hipotesis statistik untuk uji statistik dua sisi adalah

$H_{0}: \mathrm{d}=0$

$H_{1}: \mathrm{d} \neq 0$

ii. Pengambilan Keputusan

Dengan membandingkan statistik hitung dengan statistik table dengan tingkat signifikansi $(\alpha) 5 \%$. 
Jika statistik hitung < statistik tabel, maka Ho ditolak

Jika statistik hitung > statistik tabel, maka Ho diterima

b. Selisih nilai rata-rata antar aspek

Setelah melakukan Uji Wilxocon menggunakan SPSS 16.0 for windows, selanjutnya dicari Selisih nilai rata-rata antar aspek digunakan untuk melihat nilai kesenjangan antara aspek sebelum dan sesudah mengikuti program SPP. Selisih yang dimaksud disini adalah selisih antara skor rata-rata penilaian responden. Cara ini merupakan tindak lanjut setelah melakukan uji Wilcoxon untuk melihat signifikansi perbedaan antara aspek sebelum dengan sesudah mengikuti program SPP.

\section{HASIL DAN PEMBAHASAN}

\section{Profil dan Jenis Usaha Kelompok SPP}

Berdasarkan hasil survey yang dilakukan, Kecamatan Wangon telah berhasil membentuk kelompok SPP sebanyak 47 kelompok yang terdiri dari 5-45 anggota per kelompok dan tersebar di 12 desa. Dengan profesi sebagian besar adalah sebagai ibu rumah tangga dan pendidikan yang ditempuh mulai dari SD sampai SLTA, kelompok SPP Di Kecamatan Wangon telah mengalami peningkatan. Terlihat dari jumlah peminjaman rata-rata mencapai Rp69.723.000 per kelompok.

\section{Demografi Kelompok SPP Kecamatan Wangon}

Berikut ini perkembangan Kelompok SPP Di kecamatan Wangon .

Tabel 2. Responden Berdasarkan Jenis Usaha

\begin{tabular}{|l|l|l|}
\hline Jenis usaha & Jumlah & Presentase \\
\hline Pedagang & 16 & 51.6 \\
\hline Pengrajin & 4 & 12.9 \\
\hline Petani & 7 & 22.6 \\
\hline Peternak & 2 & 6.45 \\
\hline lain-lain & 2 & 6.45 \\
\hline Jumlah & $\mathbf{3 1}$ & $\mathbf{1 0 0 . 0}$ \\
\hline
\end{tabular}

Sumber: Data Primer, diolah, 2014

Berdasarkan data tersebut terlihat bahwa sebanyak 16 responden (51.6\%) mengelola usaha dagang meliputi dagang sale pisang, peralatan rumah tangga, jajanan, dan lain-lain. Sebanyak 4 responden (12.9 \%) mengelola usaha sebagai pengrajin bulu mata dan mengelola gula jawa. Sebanyak 7 responden (22.6\%) mengelola usaha sebagai petani. Sebanyak 2 responden (6.45 \%) mengelola usaha sebagai peternak lele dan ikan. Sebanyak 2 (6.45 \%) responden mengelola usaha lain-lain diantaranya: sebagai tukang kreditan dan rias penganten. 


\section{Pengelompokan Variabel}

Berdasarkan data kuisioner yang telah didapat, terdapat 2 pengelompokan variabel, yaitu:

\section{a. Pendapatan dan Kesejahteraan Sebelum Mengikuti Program SPP PNPM-MPd.}

Berdasarkan data kuisioner yang terkumpul, hanya 19 responden yang mengisi pendapatan usahanya. Hal itu dikarenakan, saat sebelum mengikuti program SPP hanya 19 responden yang menjalankan usahanya. Sedangkan sisanya hanya menjalankan kegiatan sebagai ibu rumah tangga. Untuk melihat pendapatan yang diperoleh dari hasil usaha yang dikelola oleh responden sebelum menerima Program Dana Bergulir PNPM-MPd dapat dilihat pada table berikut ini.

Table 3. Pendapatan Sebelum Mengikuti Program SPP

\begin{tabular}{|c|c|c|}
\hline Pendapatan & Jumlah & Presentase \\
\hline < Rp1.000.000 & 9 & 47.4 \\
\hline $\mathrm{Rp} 1.000 .000-\mathrm{Rp} 1.500 .000$ & 6 & 31.6 \\
\hline $\mathrm{Rp} 1.500 .001-\mathrm{Rp} 2.000 .000$ & 3 & 15.8 \\
\hline $\mathrm{Rp} 2.000 .001-\mathrm{Rp} 2.500 .000$ & - & - \\
\hline > Rp2.500.001 & 1 & 5.3 \\
\hline Jumlah & 19 & 100.0 \\
\hline
\end{tabular}

Sumber: Data Primer, diolah, 2014

Berdasarkan table diatas dapat dilihat bahwa sebanyak 1 responden (5.3\%) pendapatan hasil usahanya lebih dari Rp2.500.000. sebanyak 3 responden (15.8\%) pendapatan hasil usahanya sebesar Rp1.500.001 sampai Rp2.000.000. Sebanyak 6 responden (31.6 \%) pendapatan hasil usahanya sebesar Rp1.000.000 sampai Rp1.500.000. Sebanyak 9 responden (47.4 \%) pendapatan hasil usahanya kurang dari Rp1.000.000. Dari tabel diatas, terlihat bahwa pendapatan usaha yang diperoleh masih tergolong kecil sehingga jika dilihat kesejahteraan kelompok perempuan masih dalam taraf rendah karena untuk memenuhi kebutuhan sehari-hari masih kurang mengingat tanggungan responden dalam rumah tangga cukup besar.

\section{b. Pendapatan dan Kesejahteraan Sesudah Mengikuti Program SPP PNPM-MPd}

Berdasarkan data kuisioner yang dikumpulkan, hanya 20 responden yang mengisi tentang pendapatan usaha setelah mengikuti program SPP. Hal itu dikarenakan tidak semua responden mengguanakan dana pinjaman untuk mengembangkan usahanya. Untuk melihat pendapatan yang diperoleh dari hasil usaha yang dikelola oleh responden sebelum menerima Program Dana Bergulir PNPM-MPd dapat dilihat pada table berikut ini. 
Tabel 4. Pendapatan Sesudah Mengikuti Program SPP

\begin{tabular}{|c|c|c|}
\hline Pendapatan & Jumlah & Presentase \\
\hline$<$ Rp1.000.000 & 5 & 25.0 \\
\hline $\mathrm{Rp} 1.000 .000-\mathrm{Rp} 1.500 .000$ & 4 & 20.0 \\
\hline $\mathrm{Rp} 1.500 .001-\mathrm{Rp} 2.000 .000$ & 5 & 25.0 \\
\hline $\mathrm{Rp} 2.000 .001-\mathrm{Rp} 2.500 .000$ & 2 & 10.0 \\
\hline$>$ Rp2.500.001 & 4 & 20.0 \\
\hline Jumlah & 20 & 100.0 \\
\hline
\end{tabular}

Sumber: Data Primer, diolah, 2014

Berdasarkan table diatas dapat dilihat bahwa sebanyak 2 responden (10 \%) pendapatan dari hasil usahanya sebesar Rp2.000.001 sampai Rp2.500.000. Sebanyak 4 responden (20 \%) pendapatan hasil usahanya sebesar Rp1.000.000 sampai Rp1.500.000. Sebanyak 4 responden (20 \%) pendapatan hasil usahanya lebih dari Rp2.500.001. Sebanyak 5 responden (25 \%) pendapatan hasil usahanya sebesar Rp1.500.001 sampai Rp2.000.000 dan sebanyak 5 responden (25\%) pendapatan hasi usahanya kurang dari Rp1.000.000. Berdasarkan table diatas dapat dilihat bahwa kelompok Simpan Pinjam Perempuan Di Kecamatan Wangon telah mengalami kemajuan dibidang ekonomi setelah mengikuti program SPP PNPM-MPd sehingga taraf kesejahteraan meningkat seiring pendapatan yang meningkat.

\section{Pengujian dan Hasil Analisis}

\section{a. Pengujian Data}

1) Pengujian Data Kualitatif

Pengujian instrument data kualitatif yang dipakai dalam penelitian ini, yaitu menggunakan teknik triangulasi data:

a) Membandingkan data pengamatan dengan hasil wawancara

Dalam hal ini peneliti membandingkan data kualitatif yang diperoleh lebih dulu yang dilaksanakan dengan metode in-depth interview, kemudian diambil kembali data kuantitatif. Sehingga sehingga peneliti dapat mengetahui hubungan apa yang dikatakan saat melakukan wawancara (in- depth interview) dengan jumlah angka, apakah data yang disampaikan pada saat hasil dari wawancara sama atau berbeda dengan penelitian kuantitatif.

b) Membandingkan apa yang dikataka responden didepan umum dengan apa yang dikatakan secara pribadi.

Untuk membandingkan apa yang dikatakan responden didepan umum dengan apa yang dikatakan saat melakukan wawancara in-depth interview, peneliti berkesempatan 
mengikuti diskusi yang diadakan UPK di Balai Desa Jambu Kecamatan Wangon pada 13 September 2014 yang dihadiri 31 responden kelompok SPP dan kelompok UEP Kecamatan Wangon. Sehingga peneliti dapat membandingkan kedua data tersebut.

c) Membandingkan apa yang dikatakan waktu diteliti dengan sepanjang waktu. Peneliti membandingkan apa yang dikatakan saat melakukan in- depth interview dengan pertemuan sesudahnya dalam jangka waktu 8 hari sesudah in depth interview (saat melakukan penelitian kuantitatif dan diskusi yang dilakukan UPK Wangon).

d) Membandingkan keadaan dan perspektif seseorang dengan pendapat berbagai sumber lain.

Membandingkan keadaan dan perspektif responden dengan pendapat sumber lain, peneliti meminta pendapat salah satu pengurus UPK Wangon mengenai keadaan usaha dan perspektif terhadap kinerja kelompok SPP yang dijalankan responden.

e) Membandingkan hasil wawancara dengan isi dokumen yang berkaitan Dalam hal ini, peneliti membandingkan hasil wawancara yang didapat dari perwakilan kelompok SPP Kecamatan Wangon mengenai kinerja kelompok sebelum dan sesudah mengikuti program ini dan membandingkan kembali dengan data kuantitatif yang diperoleh pada penelitian sesudah meakukan wawancara.

2) Pengujian Data Kuantitatif

Pada Metode ini, menggunakan data pendapatan atau omzet serta hasil jawaban pertanyaan yang menggunakan skala likert yang diperoleh melalui kuisioner dan diolah mengguanakan program SPSS 16.0 for Windows. Adapun pengujian data kuantitatif dalam penelitian ini menggunakan Uji Kualitas Data (Uji Normalitas).

a) Uji Normalitas

Penggunaan uji normalitas untuk mengetahui apakah data tentang pendapatan kelompok SPP sebelum dan sesudah menerima bantuan dana bergulir dari PNPM-MPd berdistribusi normal atau tidak.

Berdasarkan hasil uji normalitas menggunakan software SPSS 16 for windows, diketahui dari nilai Shapiro-Wilks (dikarenakan jumlah sampel penelitian < 50) bahwa nilai asympotic significant $<$ Alfa $(\alpha=0.05)$ untuk variabel pendapatan sebelum mengikuti program SPP PNPM Mandiri Perdesaan asympotic significant (0.00) < Alfa $(\alpha=0.05)$ dan sesudah mengikuti program SPP PNPM Mandiri Perdesaan asympotic significant (0.001) < Alfa ( $\alpha=0.05)$. Sedangkan berdasarkan hasil uji normalitas untuk variabel tingkat kesejahteraan sebelum mengikuti program SPP PNPM Mandiri Perdesaan asympotic significant $(0.185)>$ Alfa $(\alpha=0.05)$ dan sesudah mengikuti program SPP PNPM-MPd asympotic significant (0.085) > Alfa $(\alpha=0,05)$. 
Dengan demikian, untuk teknik analisis akan menggunakan analisis NonParametrik. Karena untuk data pendapatan sebelum dan sesudah program SPP tidak berdisribusi normal (berdasarkan lampiran 2).

\section{b. Pengujian Hipotesis}

1) Hasil Analisis Data Kualitatif

Sebagai dasar untuk memenuhi kriteria pengambilan data kualitatif, dalam penelitian ini memakai metode triangulasi. Setelah melakukan pengujian dan melakukan in-depth interview, maka dapat diperoleh hasil penelitian kualitatif yang diurutkan berdasarkan hipotesis sebagai berikut:

Tabel 5. Indikator Wawancara Sebelum dan Sesudah mengikuti SPP

\begin{tabular}{|c|c|c|c|c|c|c|}
\hline $\begin{array}{l}\text { a.Sebelum mengikuti } \\
\text { SPP }\end{array}$ & R 1 & R 2 & R 3 & R 4 & R 5 & R 6 \\
\hline $\begin{array}{l}\text { 1. Keadaan ekonomi } \\
\text { desa }\end{array}$ & Cukup & Kurang & Kurang & Kurang & Cukup & Cukup \\
\hline 2. Pendapatan & Kurang & Cukup & Cukup & Cukup & Cukup & Cukup \\
\hline 3. Kebutuhan hidup & Cukup & Cukup & Kurang & Cukup & Cukup & Kurang \\
\hline 4. Peluang usaha & Kurang & Kurang & Cukup & Kurang & Kurang & Cukup \\
\hline $\begin{array}{ll}\text { 5. } & \text { Tingkat } \\
& \text { keterampilan }\end{array}$ & Kurang & Baik & Kurang & Cukup & Baik & Baik \\
\hline $\begin{array}{l}\text { b.Sesudah mengikuti } \\
\text { SPP }\end{array}$ & R 1 & $\mathbf{R} 2$ & R 3 & R 4 & R 5 & R 6 \\
\hline $\begin{array}{l}\text { 1. Keadaan ekonomi } \\
\text { desa }\end{array}$ & $\begin{array}{l}\text { sangat } \\
\text { baik }\end{array}$ & baik & baik & baik & baik & baik \\
\hline 2. Pendapatan & Baik & baik & baik & baik & baik & baik \\
\hline 3. Kebutuhan hidup & Baik & baik & baik & baik & baik & baik \\
\hline 4. Peluang usaha & Baik & baik & baik & baik & baik & cukup \\
\hline $\begin{array}{ll}5 . & \text { Tingkat } \\
& \text { keterampilan } \\
\end{array}$ & Baik & baik & baik & baik & baik & baik \\
\hline $\begin{array}{l}\text { 6. } \begin{array}{l}\text { Tanpa /dengan } \\
\text { bantuan }\end{array}\end{array}$ & $\begin{array}{l}\text { dengan } \\
\text { bantuan }\end{array}$ & $\begin{array}{l}\text { dengan } \\
\text { bantuan }\end{array}$ & $\begin{array}{l}\text { dengan } \\
\text { bantuan }\end{array}$ & $\begin{array}{l}\text { dengan } \\
\text { bantuan }\end{array}$ & $\begin{array}{l}\text { dengan } \\
\text { bantuan }\end{array}$ & $\begin{array}{l}\text { dengan } \\
\text { bantuan }\end{array}$ \\
\hline 7. Kendala & Ada & ada & tidak & tidak & ada & tidak \\
\hline $\begin{array}{ll}\text { 8. } & \text { Partisipasi } \\
\text { kelompok }\end{array}$ & aktif & aktif & aktif & aktif & aktif & aktif \\
\hline
\end{tabular}

Sumber: data diolah, 2014

a) Pendapatan sebelum dan sesudah mengikuti program SPP

Setelah responden dimintai keterangan mengenai hal tersebut, secara umum responden memberikan pendapat yang sama. Hal ini terungkap dari in-depth interview yang dilakukan. Berdasarkan indikator 1 dan 2 pada tabel 7, terlihat bahwa antara sebelum dan sesudah mengikuti program SPP terdapat perbedaan. Dimana sebelumnya, segi ekonomi dan pendapatan didesanya masih biasa saja atau cukup. Sedangkan setelah mengikuti program SPP, terjadi peningkatan atau menjadi lebih baik. Mereka berpendapat bahwa jika pengusaha dalam hal ini kaum perempuan yang mengikuti program SPP 
mendapat pinjaman dana atau modal yang cukup tanpa persyaratan yang berat (jaminan Bukti Pemilik Kendaraan Bermotor (BPKB) atau surat tanah) maka pendapatan yang dihasilkan dari usahanya akan meningkat karena modal yang cukup serta beban untuk pengembalian pinjaman yang ringan, seperti hasil wawancara berikut:

Responden 1:

"untuk sekarang ya mas, antusias kaum perempuan membuka usaha sangat tinggi ya mas, apalagi dengan modale ada yang nanggung dan persyaratan yang sangat mudah yaitu hanya dengan fotocopy ktp dan tanda tangan suami."

Jadi, menurut beliau yang berwirausaha dengan berjualan aksesoris (Tupperware), memperoleh pinjaman yang cukup dengan persyaratan yang mudah akan membantu untuk pengembangan usaha sehingga dapat menghasilkan pendapatan yang lebih.

Sama seperti responden diatas, responden lain juga menyebutkan kemudahan mendapatakan modal merupakan salah satu hal untuk meningkatkan pendapatan melalui usaha yang dijalankan. Seperti hasil wawancara berikut:

Responden 2:

"Antusias sekali saya mas untuk berwirausaha karena ibu-ibu disini mendapat pinjaman dari program SPP tanpa persyaratan yang sulit seperti jaminan STNK, rumah dan lain-lain."

Pendapat itu sesuai dengan responden 3, 4 dan 5 yang berpendapat membuka usaha baru setelah mendapatkan pinjaman modal dari PNPM-MPd. Berdasarkan hasil wawancara diatas, memang terjadi perbedaan pendapatan antara sebelum dan sesudah yang mengalami peningkatan dengan modal dari pinjaman yang cukup dan persyaratan yang mudah, maka Hipotesis pertama dinyatakan diterima.

b. Tingkat kesejahteraan sebelum dan sesudah mengikuti program SPP

Sesudah responden dimintai keterangan mengenai hal tersebut, secara umum responden memberikan pendapat yang sejenis. Berdasarkan indikator 3, 4, dan 5 pada tabel 7. Terlihat bahwa antara sebelum dan sesudah mengikuti program SPP terdapat perbedaan. Dimana sebelumnya, segi kebutuhan hidup, peluang usaha, dan keterampilan didesanya masih biasa saja atau cukup. Sedangkan setelah mengikuti program SPP, terjadi peningkatan atau menjadi lebih baik. Hal ini terungkap setelah peneliti melakukan indepth interview, mereka beranggapan jika kesejahteraan akan meningkat setelah mengikuti program SPP PNPM-MPd. Seperti hasil wawancara berikut:

Responden 3:

"Setelah saya mengikuti program ini ya mas, Taraf hidup keluarga saya juga naik walaupun gak banyak ya, tapi lumayan mas. Ya karena pendapatan yang bertambah juga dari usaha saya."

Pendapat di atas sama dengan yang diungkapkan oleh responden 1, 2, 4, 5, dan 6 yang menyatakan bahwa setelah mengikuti program ini, terjadi kenaikan taraf hidup. Hal serupa dengan responden diatas, responden lain juga mengungkapkan bahwa 
kemampuan (skill) juga meningkat tanpa disadari karena mendapat motivasi dari kemudahan pinjaman program SPP PNPM-MPd. Seperti hasil wawancara berikut:

Responden 6:

"Kemampuan ibu-ibu disini sekarang ya meningkat, yang dulunya Cuma tergantung sama suami sekarang sudah membuat usahanya sendiri"

Jadi, menurut beliau kemampuan (skill) dari anggota kelompok SPP akan meningkat secara tidak langsung karena keinginan untuk belajar berwirausaha melalui berbagai sumber seperti televisi maupun informasi dari teman. Pendapat ini sama dengan yang dikemukakan oleh responden 1, 2, 3, 4, dan 5 yang berpendapat jika kemampuan kelompok perempuan meningkat setelah mengikuti program ini.

Berdasarkan hasil wawancara diatas, memang terdapat perbedaan yang signifikan dan meningkat dinilai dari kesejahteraan ekonomi antara sebelum dan sesudah mengikuti program SPP PNPM-MPd. Sehingga hipotesis kedua dinyatakan diterima.

2) Hasil Analisis Data Kuantitatif

a. Uji Data Dua Sampel Berhubungan / Dependent (Uji Wilxocon)

Setelah melakukan pengujian data kualitatif dan diperoleh hasilnya melalui in depth interview, maka dapat kita ketahui perbedaan pendapatan antara variabel sebelum mengikuti program SPP dan variabel sesudah mengikuti program SPP. dikarenakan penelitian ini menggunakan model eksploratori sekuensial yaitu melakukan pengumpulan dan pengujian data kualitatif dan diikuti analisa kuantitatif.

Untuk mengetahui perbedaan masing-masing variabel antara pendapatan sebelum mengikuti program SPP dan pendapatan sesudah mengikuti program SPP, akan digunakan uji wilxocon. Dengan menilai Sig pada hasil SPSS 16.0 for windows dapat disimpulkan jika nilai Sig $<0.05$ maka $H_{0}$ ditolak, dan sebaliknya jika nilai $\operatorname{Sig}>0.05$ maka $H_{0}$ diterima.

Tabel 6. Hasil Uji Statistic Wilcoxon Pendapatan Usaha Sebelum dan Sesudah Mengikuti Program SPP

\begin{tabular}{|c|c|}
\hline Nilai & $\begin{array}{c}\text { Pendapatan Sebelum dan } \\
\text { Sesudah Program SPP }\end{array}$ \\
\hline $\mathrm{Z}$ & -3.652 \\
\hline Asymp. Sig (2-tailed) & 0.000 \\
\hline$\alpha$ (Alpha) & 0.05 \\
\hline
\end{tabular}

Sumber: data diolah, 2014

Berdasarkan hasil dari tabel uji wilcoxon diatas yang menggunakan SPSS 16.0 for Windows untuk masing-masing variabel, sebagai berikut: 
1. Hipotesis (Hipotesis Pertama)

$H_{1}$ : Terdapat perbedaan pendapatan pada kelompok simpan pinjam perempuan sesudah mengikuti program SPP PNPM Mandiri Perdesaan.

a. Pengambilan Keputusan

- Dengan membandingkan statistik hitung dengan statistik tabel.

Jika statistik hitung < statistik tabel, maka $H_{0}$ ditolak

Jika statistik hitung > statistik tabel, maka $H_{0}$ diterima

- $\quad$ Statistik hitung

Menghitung statistik uji dari Wilcoxon :

Dari output terlihat bahwa terlihat dari 20 data, tidak ada data (0 data) yang mempunyai beda-beda negatif, dan 20 data bernilai positif dan ada 3 data yang sama (ties). Dalam uji Wilcoxon, yang dipakai adalah jumlah beda-beda yang paling kecil, karena itu dalam kasus ini diambil beda-beda negatif, yaitu 0.00 (lihat output pada kolom 'sum of ranks'). Dari angka ini didapat ujia Wilcoxon (T) adalah 0.00 .

- Statistik tabel

Dengan melihat tabel Wilcoxon ( dapat dilihat pada tabel statistik), untuk n (jumlah data) = 20, uji satu sisi dan tingkat signifikan $(\alpha)=5 \%$, maka didapatstatistik Wilcoxon $=60$

Keputusan : Karena statistik hitung < statistik tabel, maka $H_{0}$ ditolak. Dasar pengambilan keputusan berdasarkan probabilitas :

- Jika probabilitas $>0,05$, maka $H_{0}$ diterima

- Jika probabilitas $<0,05$, maka $H_{0}$ ditolak

Terlihat bahwa pada kolom asymp sig (2-tailed) untuk diuji 2 sisi adalah 0.000 . Disini didapat probabilitas dibawah 0,05 , maka $H_{0}$ ditolak. Dengan demikian Hipotesis alternative diterima. Peneliti membuat kesimpulan bahwa terdapat perbedaan pendapatan pada kelompok simpan pinjam perempuan sesudah mengikuti program SPP PNPM-MPd dan sesuai dengan hasil penelitian kualitatif yang dilakukan sebelumnya.

Tabel 7. Hasil Uji Statistik Wilcoxon Tingkat Kesejahteraan Sebelum dan Sesudah Mengikuti Program SPP

\begin{tabular}{|l|c|}
\hline \multicolumn{1}{|c|}{ Nilai } & $\begin{array}{c}\text { Kesejahteraan Sebelum dan Sesudah } \\
\text { Program SPP }\end{array}$ \\
\hline $\mathrm{Z}$ & -4.876 \\
\hline Asymp. Sig (2-tailed) & 0.000 \\
\hline$\alpha$ (Alpha) & 0.05 \\
\hline
\end{tabular}

Sumber: data diolah,2014

Berdasarkan hasil dari table uji wilcoxon diatas yang menggunakan SPSS 16.0 for Windows untuk masing-masing variabel, sebagai berikut: 
2. Hipotesis (Hipotesis Kedua)

$H_{1}$ :Terdapat perbedaan tingkat kesejahteraan kaum perempuan sebelum dan sesudah mengikuti program SPP.

a. Pengambilan Keputusan

- Dengan membandingkan statistik hitung dengan statistik tabel.

Jika statistik hitung < statistik tabel, maka $H_{0}$ ditolak

Jika statistik hitung > statistik tabel, maka $H_{0}$ diterima

- $\quad$ Statistik hitung

Menghitung statistik uji dari Wilcoxon :

Dari output terlihat bahwa terlihat dari 31 data, tidak ada data (0 data) yang mempunyai beda-beda negatif, dan 20 data bernilai positif dan tidak ada (0 data) yang sama (ties). Dalam uji Wilcoxon, yang dipakai adalah jumlah beda-beda yang paling kecil, karena itu dalam kasus ini diambil beda-beda negatif, yaitu 0.00 (lihat output pada kolom 'sum of ranks'). Dari angka ini didapat uji Wilcoxon (T) adalah 0.00 .

- Statistik tabel

Dengan melihat tabel Wilcoxon (dapat dilihat pada tabel statistik), untuk n (jumlah data) = 31, uji satu sisi dan tingkat signifikan $(\alpha)=5 \%$, maka didapat statistik Wilxocon $=163$

Keputusan :

Karena statistik hitung < statistik tabel $(0<163)$, maka Ho ditolak. Dasar pengambilan keputusan berdasarkan probabilitas :

- Jika probabilitas $>0,05$, maka $H_{0}$ diterima

- Jika probabilitas $<0,05$, maka $H_{0}$ ditolak

Terlihat bahwa pada kolom asymp sig (2-tailed) untuk diuji 2 sisi adalah 0.000 . Disini didapat probabilitas dibawah 0,05 , maka $H_{0}$ ditolak. Dengan demikian Hipotesis alternatif diterima. Peneliti membuat kesimpulan bahwa Terdapat perbedaan tingkat kesejahteraan pada kaum perempuan antara sebelum dan sesudah mengikuti program SPP.

b. Selisih Nilai Skor Rata-rata Berdasarkan Masing-masing Aspek Kesejahteraan Sebelum Dan Sesudah Mengikuti program SPP

Setelah melakukan uji Wilcoxon pada hipotesis 2, perlu dilihat selisih antara kesejahteraan kaum perempuan sebelum dan sesudah mengikuti program SPP (diperoleh dari pengurangan kesejahteraan kaum perempuan sebelum dengan sesudah mengikuti program SPP). Tabel Selisih nilai kesejahteraan kaum perempuan sebelum dan sesudah mengikuti program SPP. 
Penerapan Dana Bergulir Kelompok Simpan Pinjam Perempuan...

Tabel 8. Skor Tingkat Kesejahteraan

\begin{tabular}{|c|c|}
\hline Nilai Skor Rata-rata & $\begin{array}{c}\text { Tingkat Kesejahteraan } \\
\text { Kaum Perempuan }\end{array}$ \\
\hline Sebelum mengikuti program SPP & 3.1 \\
\hline Sesudah mengikuti program SPP & 4.2 \\
\hline Selisih skor nilai & $\mathbf{- 1 . 2}$ \\
\hline
\end{tabular}

Sumber: data diolah, 2014

Dari tabel dapat dilihat selisih tingkat kesejahteraan sebesar - 1.2. Jika dilihat menggunakan skala Likert mengenai Kesejahteraan kaum perempuan tadi, kesejahteraan kaum perempuan sebelum mengikuti program SPP secara umum terletak pada rentang skala Biasa Saja dengan nilai 3.1 sedangkan kesejahteraan kaum perempuan sesudah mengikuti program SPP secara umum terletak pada skala sangat baik dengan nilai 4.2 dan memiliki selisih nilai -1.2 ini berarti kesejahteraan kaum perempuan sebelum mengikuti program SPP jauh berbeda dengan tingkat kesejahteraan kaum perempuan sesudah mengikuti program SPP yang cenderung memberikan hasil lebih baik dan sesuai dengan penelitian kualitatif yang dilakukan sebelumnya.

\section{PEMBAHASAN}

Penelitian ini menunjukan bahwa terdapat perbedaan pendapatan usaha antara sebelum dan sesudah mengikuti program SPP PNPM-MPd dan terdapat perbedaan tingkat kesejahteraan sebelum dan sesudah mengikuti program SPP PNPM-MPd di Kecamatan Wangon. Berikut akan dibahas untuk masing-masing hipotesis:

a. Pendapatan sebelum dan sesudah mengikuti program SPP PNPM-MPd

Hipotesis pertama $\left(H_{1}\right)$ yaitu terdapat perbedaan pendapatan sebelum dan sesudah mengikuti program SPP PNPM-MPd, diterima. Terlihat dari perbandingan persentase antara sebelum dan sesudah mengikuti program SPP. Dimana sebelum mengikuti program SPP, $47.4 \%$ atau 9 orang yang mempunyai pendapatan dibawah Rp1,000,000 dan $5.3 \%$ atau hanya 1 orang yang mempunyai pendapatan diatas Rp2,500,001. Sedangkan sesudah mengikuti program SPP, 25 $\%$ atau 5 orang yang mempunyai pendapatan dibawah Rp1,000,000 dan $20 \%$ atau 4 orang yang mempunyai pendapatan diatas $\mathrm{Rp} 2,500,001$. Hal ini menunjukan masih banyaknya kaum perempuan yang berpenghasilan dibawah Rp1,000,000 sebelum mengikuti program SPP, hasil sebaliknya ditunjukan sesudah mengikuti program SPP dimana terjadi peningkatan pendapatan diatas Rp2,500,001 sehingga penyaluran dana bergulir PNPM Mandiri melalui program SPP memberikan dampak positif dengan meningkatnya kinerja keuangan (pendapatan usaha) dan meningkatkan modal untuk dapat mengembangkan usaha terutama kaum perempuan di Kecamatan Wangon. 
Sesuai dengan teori yang dikemukan PSAK 23 (2009), pendapatan adalah arus masuk bruto dari manfaat ekonomi yang timbul dari aktivitas normal perusahaan selama suatu periode bila arus masuk itu mengakibatkan kenaikan ekuitas, yang tidak berasal dari kontribusi penanam modal.

Penelitian ini sama dengan penelitian yang dilakukan oleh Erni dan Sukamto (2013), yang menyatakan dengan adanya program dana bergulir yang diberikan pemerintah melalui Badan Keswadayaan Masyarakat (BKM) modal usaha yang diberikan sangat membantu dalam pengembangan usaha-usaha masyarakat dalam meningkatkan pendapatan. Hal ini sesuai juga dengan penelitian yang dikemukakan oleh Khun dan Chamratrithirong (2011), Surya (2011), Rantung (2014) dan Yentifa (2012) yang menyatakan bahwa pelaksanaan dana bergulir dapat meningkatkan pendapatan masyarakat.

Sesuai dalam penelitian yang dilakukan dilapangan, usaha yang berasal dari pinjaman program SPP di Kecamatan Wangon lebih memberikan manfaat bagi mereka yang tergabung dalam keanggotaan pada program SPP karena modal yang didapat jauh lebih tinggi dan persyaratan yang terbilang mudah. Dengan demikian perputaran uang pada usaha mereka akan lebih baik sehingga kinerja keuangan (menghasilkan pendapatan atau omzet) akan meningkat dibandingkan dengan usaha sebelum mengikuti program SPP karena modal yang rendah walaupun tanpa pinjaman. Hal ini terjadi karena pada umumnya pendiri usaha takut untuk melakukan pinjaman karena persyaratan yang sulit dan masa pengembalian pinjaman yang pendek.

Sesuai dengan yang dikemukakan oleh Harjito (2008) kinerja keuangan mengindikasikan apakah strategi perusahaan, implementasi strategi, dan segala inisiatif perusahaan memperbaiki laba perusahaan. Pengukuran kinerja mencerminkan pengukuran hasil atas keputusan strategis, operasi dan pembiayaan dalam suatu perusahaan. Kinerja keuangan suatu perusahaan sangat bermanfaat bagi berbagai pihak (stakeholders) seperti investor, kreditur, analis, konsultan keuangan, pialang, pemerintah, dan pihak manajemen sendiri.

Adanya program SPP dari PNPM-MPd membuat kaum perempuan antusias untuk mendirikan dan mengembangkan usahanya dengan modal dari program PNPM-MPd. Karena persyaratan pinjaman yang mudah. Akan tetapi program ini memiliki kendala dari sisi pengembalian pinjaman, terdapat beberapa anggota kelompok yang pernah telat mengembalikan pinjaman. Hal ini diungkapkan oleh responden 2:

"Kalau kendala mungkin pada saat pengembalian pinjaman, ada beberapa anggota yang telat dan kalau bisa ada tambahan waktu pengembalian pinjaman, dari yang 1 tahun jadi 2 tahun."

Hal ini akan menjadi beban bagi ketua kelompok yang bertanggungjawab atas pinjaman anggotanya serta dapat menyebabkan konflik antara (ketua dan anggota) dan antara (ketua dan pengelola kegiatan). Sehingga ada usulan untuk memperpanjang masa pengembalian pinjaman. 
Penerapan Dana Bergulir Kelompok Simpan Pinjam Perempuan...

Hal ini sesuai dengan teori agency yang dikembangkan oleh Jensen dan Meckling (1976) Permasalahan yang sering terjadi yaitu adanya conflict of interest antar principal dan agent yang dapat menimbulkan masalah agency atau agency problem, dimana agent tidak bertindak sesuai dengan kepentingan principal dan hal ini akan berpengaruh kepada kinerja perusahaan.

b. Tingkat kesejahteraan Sebelum dan Sesudah mengikuti Program SPP

Hipotesis kedua $\left(\mathrm{H}_{2}\right)$ mengenai terdapat perbedaan tingkat kesejahteraan sebelum dan sesudah mengikuti program SPP PNPM-MPd, diterima. Hal ini menunjukan bahwa program SPP memberikan dampak positif dengan peningkatan kesejahteraan bagi anggota kelompok SPP karena pinjaman modal melalui program SPP yang digunakan seefisien mungkin membantu pengembangan usaha kaum perempuan.

Hal ini sesuai dengan yang dikemukakan Martono (2005), struktur modal merupakan perbandingan atau imbalan pendanaan jangka panjang perusahaan yang ditunjukkan oleh perbandingan struktur aktiva jangka panjang terhadap modal sendiri. Pendanaan dalam arti luas meliputi semua aktivitas perusahaan yang berkaitan dengan usaha mendapatkan dana yang dibutuhkan oleh perusahaan beserta usaha untuk menggunakan dana tersebut seefisien mungkin.

Penelitian ini sama dengan penelitian yang dilakukan oleh Surya (2011) yang menyatakan bahwa dampak yang dapat dilihat dengan adanya bantuan dana bergulir dari PNPM-MP adalah adanya peningkatan kualitas hidup berdasarkan indikator pendapatan, perumahan, kesehatan, pendidikan dan gizi. Hal ini sesuai juga dengan penelitian yang dikemukakan oleh Zhou (2009), Rantung (2014), Erni dan Sukamto (2013), Yentifa (2012) dan Khun dan Chamratrithirong (2011) yang menyatakan bahwa pelaksanaan program dana bergulir dapat meningkatkan kesejahteraan masyarakat dari sisi sosial maupun ekonomi.

Sesuai dengan penelitian di lapangan, terjadinya peningkatan taraf hidup disebabkan oleh keberhasilan kelompok SPP dalam memanfaatkan pinjaman untuk mengembangkan usaha yang dijalankan serta pengelolaan keuangan yang tepat. Kinerja keuangan (pendapatan) yang meningkat akan berdampak positif pada peningkatan taraf hidup secara ekonomi. Kenaikan pendapatan yang dihasilkan akan dapat membantu masyarakat khususnya kaum perempuan dalam memenuhi kebutuhan hidupnya seperti kebutuhan akan pendidikan, kesehatan, dan lainlain.

Sesuai dengan yang dikemukakan dalam Irawan dan Suparmoko (2002), bahwa pembangunan ekonomi adalah usaha-usaha untuk meningkatkan taraf hidup riil per kapita. Jadi tujuan pembangunan ekonomi disamping untuk menaikkan pendapatan nasional riil juga untuk meningkatkan produktivitas.

Pemberian pinjaman modal melalui program SPP diyakini sangat bermanfaat untuk meningkatkan kualitas hidup serta memotivasi pengguna untuk mengembalikan pinjaman tepat 
waktu sehingga mereka bisa mendapatkan pinjaman dengan dana yang lebih besar untuk mengembangkan usaha mereka.

\section{SIMPULAN}

Simpulan yang diambil dalam penelitian ini adalah: 1) Terdapat peningkatan pendapatan usaha, membuktikan terdapat perbedaan yang signifikan mengenai pendapatan usaha kelompok Simpan Pinjam Perempuan (SPP) antara sebelum dan sesudah mengikuti program SPP PNPM-MPd; 2) Terdapatnya perbedaan tingkat kesejahteraan, membuktikan Program Simpan Pinjam Perempuan (SPP) PNPM-MPd memberikan dampak positif dalam peningkatan kesejahteraan kaum perempuan.

Penelitian ini memberikan beberapa implikasi, antara lain: 1) Pelaksanaan PNPM-MPd dilaksanakan dengan tujuan untuk meningkatkan kesejahteraan masyarakat dan mengurangi angka kemiskinan. Salah satu program PNPM-MPd yaitu program SPP yang dikhususkan untuk kaum perempuan. Program ini diharapkan dapat membantu meningkatkan pendapatan usaha kelompok perempuan sehingga dapat meningkatkan kesejahteraan hidup dari sisi ekonomi maupun social; 2) Pengelola kegiatan senantiasa perlu lebih meningkatkan pengawasan serta evaluasi yang mendalam atas pelaksanaan PNPM-MPd khususnya pada program SPP sehingga pelaksanaan program dapat melebihi target yang telah direncanakan. Diperlukan juga partisipasi yang lebih dari masyarakat khususnya kelompok perempuan melalui musyawarah antar kelompok serta pemanfaatan dana bergulir yang lebih dikhususkan untuk peningkatan pendapatan melalui usaha, sehingga dapat memperlancar pelaksanaan dan capaian tujuan dari program SPP.

Penelitian ini memiliki beberap keterbatasan, antara lain: 1) Penelitian ini hanya menganalisis dari segi pendapatan atau omzet usaha kelompok perempuan, tidak mengukur dari segi pembiayaan seperti biaya produksi, biaya peluang, dan lain-lain. Untuk penelitian lebih lanjut dapat digunakan analisis yang lebih kompleks seperti analisis Harga Pokok Penjualan (HPP); 2) Penelitian ini hanya menggunakan satu objek penelitian saja, yaitu kelompok SPP di Kecamatan Wangon. Sehingga kesimpulan yang dihasilkan hanya berlaku pada kelompok SPP di Kecamatan Wangon. Untuk hasil yang lebih baik sebaiknya menggunakan objek lebih dari satu sehingga dapat diketahui perbedaan masing-masing objek tersebut dalam mengimplementasikan program SPP PNPM-MPd.

\section{DAFTAR PUSTAKA}

Barlian, R.S. 2003. Manajemen Keuangan. Edisi Kelima. Cetakan Kedua. Yogyakarta: Literata Lintas Media.

BPS. 2014. Pengangguran di Indonesia Mencapai 7.24 juta jiwa. http://www.kompas.com/ (diakses pada tanggal 24 desember 2014).

Ghozali, Imam, 2006. Aplikai Analisis Multivarite dengan SPSS, Cetakan Keempat, Badan Penerbit Universitas Diponegoro, Semarang.

Hamdi, dkk, 2013," Kegiatan Simpan Pinjam Khusus Perempuan di Kecamatan Semparuk, Sambas". Jurnal Manajemen IKM. Vol. 8, No. 2.

Harjito. 2008. Dasar-dasar Manajemen Keuangan. Edisi keempat. Universitas Muhammadiyah. Malang.

IAI. 2009. Standar Akuntansi Keuangan, PSAK No.23. Jakarta. 
Irawan dan Suparmoko, M. 2002. Ekonomika Pembangunan. Ed 6. Jakarta: BPFE UGM

Imam Ghozali. 2007. Aplikasi Analisis Multivariate dengan Program SPSS. Badan Penerbit Universitas Diponegoro. Semarang.

Jensen MC and Meckling WH (1976) Theory of the firm: Managerial behavior, agency costs, and ownership structure. Journal of Financial Economics, 3: 305-360.

JPNN. 2013. 300 Ribu Warga Banyumas Masih Miskin. http://m.jpnn. com/news. php?id= 154575 (diakses tanggal 10 Juni 2014).

Martono \& Agus Harjito, 2005, Manajemen Keuangan, EKONISA, Kampus FE UII, Yogyakarta.

Miles, Mattew B dan A. Michael Huberman (2007). Analisis Data Kualitatif, Buku sumber tentang metode-metode baru. Jakarta: Universitas Indonesia Press.

PNPM Mandiri Perdesaan tentang Cakupan Wilayah PNPM Mandiri Perdesaan. http://www.pnpmperdesaan.or.id/?page=halaman\&story id=22. (diakses pada tanggal 27 Mei 2014).

PNPM Mandiri Perdesaan tentang Cara Kerja PPK/ PNPM-Perdesaan. http://www.pnpmperdesaan.or.id/?page=halaman\&story id=27. (diakses pada tanggal 27 Mei 2014).

Rachmadi, Lexy J. Moleong, 2011. Metode Penelitian Kualitatif (Edisi Revisi). Bandung: Remaja Rosda Karya.

Rantung, G.A. 2014, "Efektifitas kelompok Simpan Pinjam Khusus Perempuan Di Kecamatan Kauditan Kabupaten Minahasa Utara". Jurnal.

Santoso, Singgih. 2008. Panduan Lengkap menguasai SPSS 16. PT Alex Media Komputindo, Jakarta.

Sawir, Agnes. 2005. Analisis kinerja Keuangan : Teori dan Aplikas. Edisi keempat Cetakan kelima. PT Gramedia Pustaka Utama:Yogyakarta.

Segal, E dan S Bruzy. 1998. Social Welfare Policy, Program, and Practice. Itasca IL: Peacock.

Sekaran, Uma. 2006. Metode Penelitian Bisnis 2 Edisi 4. Jakarta: Salemba Empat.

Sigap Bencana \& Bansos, 2011. "PNPM Turunkan Kemiskinan." http://sigapbencana-bansos.info. (diakses pada tanggal 16 Mei 2014).

Sugiyono. 2012. Metode Penelitian Kualitatif, Kuantitatif, dan Kombinasi (Mixed Methods). Bandung: Alfabeta.

Surya, Sari, 2011, “Analisis Kinerja Dana Bergulir PNPM Mandiri di Kecamatan Lubuk Begalung Kota Padang". Jurnal. Vol 7, No. 3: hal. 101-117

ZHOU Siyu, 2009, "In Search of the Determinants of Private Donation in Chinese Nation-owned Nonprofit Performing Arts Organization -- Evidences from Province-level Panel Data 1997-2008". Renmin University of China - School of Economics. 